\title{
竜巻災害の低減に向けて \\ For the Tornado Disaster Reduction
}

植松 康*

Yasushi UEMATSU

\section{1. 頻発する竜巻等突風災害とその対策}

「2005 年 12 月 25 日, 山形県庄内町榎木で JR 羽越本 線秋田発新潟行きの特急いなほ 14 号 (6 両編成) が竜巻と 思われる突風で脱線。3 両が転覆して死者 5 名, 負傷者 33 名発生」というニュースが全国を駆け巡つた。竜巻等 突風災害に対して世間の関心が一気に高まるきっかけと なった事故である。

その翌年の 2006 年 9 月 17 日, F2 の竜巻が宮崎県延岡 市の市街地を直撃した。これによって, 死者 3 名, 負傷 者 143 名という大きな人的被害が発生した。建物被害も 大きかった。さらに，それから 2 か月も経たない 11 月 7 日, 北海道佐呂間町で我が国最大級といわれる F3 の竜巻 が発生し, 死者 9 名, 負傷者 31 名をもたらした。死者 9 名は, 我が国の竜巻災害史上最大の数である。

これら一連の竜巻等突風災害を受け, 気象庁は 2008 年 3 月 26 日から「竜巻注意情報」の発表を開始した。さら に, 2010 年 5 月 27 日より「竜巻発生確度ナウキャスト」 の提供を開始した。また，2012 年 5 月 6 日北関東で発生 した竜巻(茨城県つくば市で F3)や 2013 年 9 月 2 日埼玉 県越谷市等で発生した竜巻(F2)による甚大な被害を受け, 内閣府の竜巻等突風対策局長級会議においても, 竜巻等 突風対策の強化を図るため，1. 予報情報の収集，2，災 害情報等の伝達の在り方, 3. 防災教育の充実, 4. 建造 物の被害軽減策の在り方，5. 被災者支援の在り方，につ いて議論が行われ，具体的な施策が打ち出された ${ }^{1)}$

表 1 は, 気象庁の「竜巻等突風データベース」に基づ
き, 2001 年以降の竜巻等突風確認数と人的被害を纏めた ものである。1990年茂原市の竜巻(F3) 以降に着目すると, 全国的に見れば，F3 の竜巻等突風は $5 \cdot 6$ 年に 1 回の割 合で発生しており，F1〜F2 の竜巻等突風は毎年 20 件程 度発生している。死者数はそれほど多くはないが，負傷 者数は F2～F3 クラスの竜巻が市街地を襲うと $100 〜 200$ 名に達寸る。竜巻等突風対策が急がれる所以である。

\section{2. 日本風工学会を中心とした竜巻被害低減活動}

1998 年 5 月, 日本風工学会は風災害に関わる諸問題に 積極的に対応できるよう，また防災・減災活動に主導的

表 12001 年以降の竜巻等突風発生数と人的被害

\begin{tabular}{|c|c|c|c|c|c|}
\hline \multirow{2}{*}{ 年 } & \multicolumn{3}{|c|}{ 竜巻等突風発生数(個) } & \multicolumn{2}{c|}{ 死傷者数(人) } \\
\cline { 2 - 6 } & $\mathrm{F}^{*}$ & $\mathrm{~F} 2^{*}$ & $\mathrm{~F}^{*}$ & 死者 & 負傷者 \\
\hline 2001 & 15 & 1 & 0 & 0 & 11 \\
\hline 2002 & 18 & 3 & 0 & 0 & 30 \\
\hline 2003 & 14 & 3 & 0 & 0 & 11 \\
\hline 2004 & 16 & 3 & 0 & 0 & 21 \\
\hline 2005 & 15 & 1 & 0 & 5 & 41 \\
\hline 2006 & 23 & 5 & 1 & 12 & 191 \\
\hline 2007 & 15 & 0 & 0 & 0 & 41 \\
\hline 2008 & 20 & 0 & 0 & 0 & 25 \\
\hline 2009 & 5 & 2 & 0 & 0 & 31 \\
\hline 2010 & 8 & 0 & 0 & 0 & 17 \\
\hline 2011 & 5 & 1 & 0 & 3 & 13 \\
\hline 2012 & 15 & 1 & 1 & 1 & 62 \\
\hline 2013 & 24 & 1 & 0 & 0 & 95 \\
\hline
\end{tabular}

*F1〜F3 は藤田スケール 1〜3 を表す。ただし, 気象庁に よる F0〜F1 はF1 として,F1〜F2 はF2 としてカウント。

* 東北大学大学院工学研究科都市 - 建築学専攻 教授

Professor, Department of Architecture and Building Science, Graduate School of Engineering, Tohoku University 
役割を果たせるよう「風災害研究会」を発足させた。各 地で発生する竜巻等突風や台風による風災害に対し, 組 織的な調査を行い，その成果を報告書や報告会で公表す るとともに, 各地でフォーラム等を開催するなど, 強風 被害低減を目指した社会啓発活動を実施している。特に 大きな被害をもたらした 2006 年 9 月宮崎県延岡市の竜巻, 同年 11 月北海道佐呂間町の竜巻, 2012 年 5 月北関東の竜 巻については, 文部科学省科学研究費 (特別研究促進費) により, 全国的規模で被害調査が実施された 2) 4)。また, 2007 年度には, 科学技術振興調整費による研究「竜巻等 の実態および発生予測と対策」が，日本風工学会や日本 気象学会を中心として行われた ${ }^{5)}$ 。の研究は, テーマ 1 「竜巻を生夕出す環境場及び竜巻の発生機構の研究」, テ 一マ2「竜巻等の発生予測手法及び監視技術の開発」, テ 一マ3「竜巻等による突風災害対策」に分かれており，テ 一マ3 の中にサブテーマ3-3「竜巻, ダウンバーストなど の突風に対する個人および行政レベルでの対応マニュア ルの研究」という課題が含まれていた。これに対し，筆 者を主查とするWGにより以下の項目について調查研究 を行った。

（1）竜巻等突風災害に対する地域防災計画の現状の調査

(2) 竜巻災害を受けた行政に対するヒアリング調査

(3) 佐呂間町の竜巻災害に関する住民アンケート調査

報告書には, これらに関する調查結果を縓めるととも に，最後に研究のロードマップを示した。

\section{3.「竜巻対応マニュアル作成研究会」の活動}

前述の科学技術振興調整費による研究で提案された口 ードマップに従い, さらに研究を進めるため, 2011 年 9 月, 以下のメンバーによる「竜巻対応マニュアル作成研 究会」が組織され, 調査研究活動をスタートした。

主查: 植松 康(東北大学)

幹事 : 高橋章弘(北方建築総合研究所)

池内淳子 (摂南大学)

委員: 奥田泰雄(国土技術政策総合研究所)

萩原一郎, 喜々津仁密(建築研究所)

松井正宏 (東京工芸大学)

西村宏昭 (日本建築総合試験所)

野田 稔(徳島大学)

この研究会では, 竜巻等突風災害に対する予防・減災 対策，事前準備対策，応急対策，復旧・復興対策といっ た，ある災害から次の災害までの 4 フェーズにおいて， 個人，学校および行政がとるべき行動を検討し，それぞ れの対応マニュアルを作成するための項目の整理とフロ
一を提示し，さらに研究成果の普及を図ることを目標と

している。具体的な活動は以下の通りである。

(1)近年発生した竜巻による被害実態の把握

・過去の竜巻災害調查報告書の分析

・研究会活動期間中の竜巻災害の調査

(2)竜巻災害対応に関する内閣府および自治体の動 向の調査

・地域防災計画の調査等

(3)米国における対応マニュアルの調査

・FEMAやフロリダ州の緊急対応マニュアル等

(4)被災自治体へのヒアリング調查と結果の整理 佐賀県佐賀市 (2004, F2), 宮崎県延岡市 (2006, F $2)$, 北海道佐呂間町 (2006, F3), 群馬県館林市 (2 $009, F 1 \sim F 2)$, 新潟県胎内市 $(2010, F 1)$, 茨城県 土浦市 $(2009, F 1)$, 秋田県能代市 $(2009, F 1)$, 茨 城県つくば市 $(2012$, F3), 栃木県益子町, 真岡市 (2012, F2)，青森県弘前市 (2012, F1)

(5)2012 年 5 月 6 日つくば市の竜巻災害における被災住民 の行動に関するヒアリング・アンケート調査と分析

・つくば市北条地区の住民 (541世帯) を対象とした調査

(6)被災した以下の学校へのヒアリング調查 真岡市西田井小学校 (2012年, F2), つくば市北 条小学校 (2012年, F3)

本特集は, 竜巻対応マニュアル作成研究会において, 約 2 年半にわたる活動の成果を纏めたものである。

参考文献

1) 内閣府: 「竜巻等突風対策局長級会議」報告, 2013 年 12 月 26 日 (防災情報のページ)

2) 平成 18 年度科学研究費補助金「2006 年台風 13 号に伴 う暴風・竜巻・水害の発生機構解明と対策に関寸る研 究」(研究代表者 : 真木太一) 報告書, (2013.2)

3)平成 18 年度科学研究費補助金「北海道佐呂間町で発生 した竜巻による甚大な災害に関する調查研究」(研究代 表者: 田村幸雄) 研究成果報告書, (2007.3)

4) 平成 24 年度文部科学省科学研究費補助金「平成 24 年 5 月 6 日に北関東で発生した竜巻の発生メカニズムと 被害実態の総合調査」(研究代表者: 前田潤滋) 研究成 果報告書, (2013.2)

5) 平成 19 年度科学技術振興調整費「竜巻等の実態およ び発生予測と対策」(研究代表者: 田村幸雄) 報告書, (2007.3) 